\title{
ソフトゲル微粒子の自己組織化
}

\section{Self-organization of Microhydrogels}

\section{乾 滉平}

信州大学繊維学部 化学・材料系 4 年 T 386-8567

長野県上田市常田 3-15-1

Kohei INUI

Faculty of Textile Science and Technology Shinshu university 3-15-1, Tokida, Ueda, Nagano 3868567, Japan

\section{鈴木 大介}

信州大学学術研究院（繊維学系）化学. 材料学科

国際ファイバー工学研究所（兼任）

准教授 博士（工学）

T 386-8567

長野県上田市常田 3-15-1

Daisuke SUZUKI

Graduate School of Textile Science \& Technology and Institute for Fiber

Engineering, Interdisciplinary

Cluster for Cutting Edge Research,

Shinshu University

3-15-1, Tokida, Ueda, Nagano 386-

8567, Japan
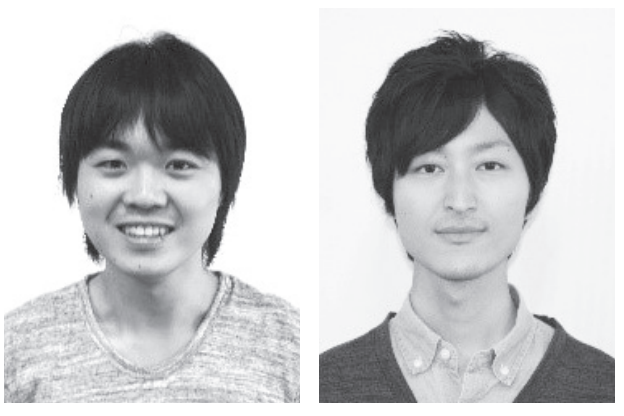

松井 秀介

信州大学大学院総合工学系研究科 生命機能・ファイバー工学専攻 後期 博士課程 1 年

T 386-8567

長野県上田市常田 3-15-1

Shusuke MATSUI

Graduate School of Textile Science \&

Technology, Shinshu university

3-15-1, Tokida, Ueda, Nagano 3868567, Japan

論文要旨：高分子ヒドロゲル微粒子は温度や $\mathrm{pH}$ などの外部刺激に対して応答し，その物理化学的性質が 可逆的に変化する『刺激応答性』を有する。また，水溶液中で膨潤し，ブラウン運動をしており，分散／凝 集といったコロイド的性質も併せ持つ。筆者らは，これまで「高分子ゲル微粒子の次元制御とマイクロ空間 場における機能制御」というコンセプトのもと研究を続けており，その中には，非平衡系の中での自己組織 化を活用した機能制御を含んでいる。特に，温度応答性の高分子である poly（ $N$-isopropyl acrylamide） (pNIPAm) から成るゲル微粒子は, その希薄分散液の乾燥後, 間隔を空けて配列し，単層の薄膜が自発的 に形成される。筆者らはこの現象に注目し，その乾燥過程を追跡する事で，ゲル微粒子の自発的な構造形成 過程を明らかにしてきた。更に, 『液滴の乾燥』といった極めてシンプルな系とは異なり，この pNIPAm ゲ ル微粒子と化学振動反応（ベローゾフ・ジャボチンスキー（BZ）反応）のカップリングを試み, 微粒子に 時間周期構造の付与を行う事で, 周期的に体積や粒子間相互作用を変化させる新奇ゲル微粒子（自律駆動ゲ ル微粒子）の開発に成功している。本稿では，筆者らが検討している『ゲル微粒子の自己組織化』研究につ いて，上述した自律駆動ゲル微粒子の話題を中心に紹介し，その発展について述べる。 
Abstract: Polymeric hydrogel particles (microgels) have "stimuli-responsiveness" and their physicochemical properties can be controlled by external stimuli such as temperature and $\mathrm{pH}$. Moreover, microgels are swollen by water, which show Brownian motion, and also possess colloidal properties such as dispersing/flocculating. The authors have been studying microgels under the concept of "dimension and function control of polymeric hydrogel particles in microscopic spatial fields", and it includes function control by utilizing self-organization in non-equilibrium system. In particular, when thermoresponsive poly ( $N$-isopropyl acrylamide) (pNIPAm) microgel dispersions are dried, non-closepacked ordered structure of microgels are assembled on substrate. We focused on this phenomenon, and clarified the spontaneous structure formation process of pNIPAm microgels by observing the drying process. Furthermore, different from a very simple system such as "droplet drying", we succeeded in the development of novel microgels (autonomously oscillating microgels) which periodically change their volume and interparticle interaction by coupling the pNIPAm microgels with chemical oscillation reaction (Belousov-Zhabotinsky (BZ) reaction). In this paper, we will mainly explain the study about "self-organization of microgels", especially, the development of the autonomously oscillating microgels.

Key words: microgels, self-organization, swelling/deswelling oscillation,

Belousov-Zhabotinsky reaction

\section{1 はじめに}

筆者らは, 高分子ヒドロゲル微粒子の研究を続けてい る。この微粒子は, 水中で大きく膨らみ, ゲルおよびコ ロイドとしての性質を兼ね備える。即ち, 温度·pHといっ た外部環境が変化する事により，その物理化学的性質が 可逆的に変化する『刺激応答性』を有する。それに加え て, 水中ではブラウン運動をしており, 分散/凝集を理 解し, 活用する機会が存在する。

筆者の研究コンセプトは,「高分子ゲル微粒子の次元 制御とマイクロ空間場における機能制御」であり, その 中には非平衡系の中での自己組織化を活用した機能制御 を含んでいる。当初, ベローゾフ・ジャボチンスキー (BZ) 反応 ${ }^{1)}$ の酸化還元振動と, ゲル微粒子の体積や粒子間 相互作用変化との同期について研究 ${ }^{2,3)}$ を始めたが，『自 己組織化』という概念が如何に深いものかということを 思い知った。生物学の研究会などでは「この微粒子が凄 いのではなく，BZ 反応が凄いだけだ」とありがたい批 評を頂くこともあった。まだ検討途中ではあるが，最近 提出した論文等をもとに, 『ゲル微粒子の自己組織化』 研究について，筆者らの研究を概説する。

\section{2 ゲル微粒子希薄分散液の乾燥に伴う自己組織化}

一般的に，ポリスチレンやシリカといった固体微粒子 を乾燥させた場合，分散媒中の分散質は液滴の縁に集合 し，リング状の構造を形成する ${ }^{4)} 。$ 一方，上述した固体 微粒子とは異なり，水で膨潤するゲル微粒子，特に，温 度応答性の高分子である poly（ $N$-isopropyl acrylamide） （pNIPAm）から成るゲル微粒子は，その希薄分散液の 乾燥後, 間隔を空けて配列し, 単層の薄膜が自発的に形 成される事が 1986 年の Pelton らの報告 ${ }^{5}$ ) や川口らに
よって記載されている ${ }^{6)}$ 。しかし，上述した固体微粒子 分散液の乾燥構造に比べ, pNIPAm ゲル微粒子分散液 の乾燥構造を扱う研究は少なく, pNIPAm ゲル微粒子 の配列過程は明らかではなかった。そこで，筆者らは， pNIPAm ゲル微粒子分散液の乾燥過程に着目し, pNIPAm ゙゙ル微粒子の自発的な構造形成過程解明を試みた。

光学顕微鏡下で観察可能な大きさの単分散 pNIPAm ゲル微粒子分散液の濃度を調節し, 基板上に滴下して自 然乾燥させた。その結果, ゲル微粒子濃度が比較的高い, または非常に低い時は（0.01 wt.\%以上，0.0005 wt.\%以 下)，透明度が高い膜が形成され，0.0006 0.001 wt.\%と いう濃度範囲おいては, 既往研究と同様に構造色を示す 薄膜が得られた $(F i g .1(B))^{7)}$ 。次に, 乾燥に伴う液滴 内の pNIPAm ゲル微粒子の挙動を光学顕微鏡により観 察した。液滴の気水界面, 液中そして基板上をそれぞれ 観察した所，液滴滴下から 20 分後には間隔を空けてゲ ル微粒子が気水界面に吸着し，並んだ構造が観察され た。60 分後には, 最密充填構造を形成し (Fig. 2 (B)), その規則構造は, 気水界面で維持されながら基板に転写 され，微粒子が並んだ薄膜を形成する事がわかった（Fig. 2 (C))。一連の検討により, 構造色を示す pNIPAm ゲ ル微粒子の薄膜は, 特定の濃度において形成されること が判明し, pNIPAm ゲル微粒子はまず気水界面に吸着
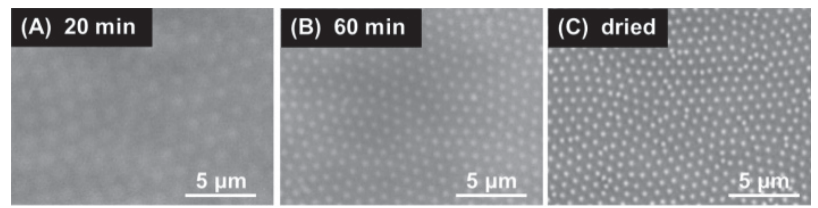

Fig. 2 (A) (B) 気水界面と（C）乾燥後基板上のゲル微粒 子薄膜の光学顕微鏡観察。それぞれ (A) $20 \mathrm{~min},(\mathrm{~B})$ $60 \mathrm{~min}, \quad(\mathrm{C})$ 乾燥後に観察。 
するため，液中には殆ど見られなくなり，そのまま転写 することから，環状の構造を形成しないことを明らかに した ${ }^{7)}$ 。この現象を活用し, 気水界面上でゲル微粒子の 集積化を行う事も可能であった。例えば，カチオン性と アニオン性のゲル微粒子を混合する際に, 電解質の有無 により，粒子間隔が空いた構造（Fig. 2(A) 参照）や, 鎖状凝集構造へと調節することが可能であった ${ }^{8,9)}$ 。現 在は, このゲル微粒子の乾燥散逸構造の体系化に向けた 一連の検討を進めているところである。

\section{3 ゲル微粒子への時間周期構造の付与}

上述した『液滴の乾燥』といった極めてシンプルな系 とは異なり，筆者らは，この pNIPAm ゲル微粒子と化 学反応のカップリングを試み, 微粒子に時間周期構造の 付与を行った。

\section{$3 \cdot 1$ 自律駆動ゲル微粒子の設計}

時間周期性を与えるために, 周期的な酸化還元変化を 生み出す BZ 反応 ${ }^{1)}$ を選択した。 $\mathrm{BZ}$ 反応は, 生体の代 謝反応である TCA 回路の化学モデルとして, 人工的に 模倣して作られた化学振動反応である。BZ 反応の研究 は古くより多様なものが存在し, 実際に高分子溶液と カップリングした系 ${ }^{10)}$ や，ポリアクリルアミドゲル中で のパターン観察 ${ }^{11)}$, pNIPAm ゲル中での自励振動ゲル ${ }^{12)}$ などが有名である。筆者は, 吉田の報告にならい ${ }^{12)}$,『コ ロイド分散系』における時間構造についての検討を切り 拓いてきた。

微粒子の設計としては, BZ 反応の金属触媒であるル テニウムトリスビピリジン錯体 $\left(\mathrm{Ru}(\mathrm{bpy})_{3}\right)$ を, pNIPAm ゲル微粒子内に共有結合する（Fig. 3)。この事で, $\mathrm{BZ}$ 反応の進行と共に, $\mathrm{Ru}$ 錯体部位の酸化還元状態の 違いが, pNIPAm ゲル微粒子の状態に影響を与えるこ ととなる。つまり, 従来の温度応答性ゲル微粒子とは異 なり, 一定温度下で $\mathrm{Ru}(\mathrm{bpy})_{3}$ 部位が酸化／還元の変化 を起こすと, それと同期したゲル微粒子の体積変化に繋 がるわけである。

筆者らはこれまでに, イオン強度, モノマー濃度, 開 始剂濃度等の各種微粒子重合条件を精査する事により, 得られるゲル微粒子の大きさが膨潤状態において直径〜 $100-〜 10,000 \mathrm{~nm}$ のものを，それぞれ単分散で合成す る事に成功している。

Fig. 4 には， $\mathrm{Ce}^{4+}$ および $\mathrm{Ce}^{3+}$ 水溶液を用い，微粒子内 に固定された $\mathrm{Ru}(\mathrm{bpy})_{3}$ を強制的に酸化状態 $\left(\mathrm{Ru}(\mathrm{bpy})_{3}{ }^{3+}\right)$ と還元状態 $\left(\mathrm{Ru}(\mathrm{bpy})_{3}{ }^{2+}\right)$ に保持し, 流体力学的直径 の温度変化を測定した結果を示す。一定温度下において, $\mathrm{Ru}(\mathrm{bpy})_{3}$ が酸化状態にあるゲル微粒子は還元状態にあ るものと比較すると, より大きなサイズを示しているこ
とがわかる。また, 酸化状態にあるゲル微粒子の体積相 転移温度が, 還元状態のものと比べ数 ${ }^{\circ} \mathrm{C}$ 高温側にシフト していることも読み取れる。更に, 酸化還元状態に関わ らず，体積相転移温度を超えると微粒子が凝集する様子 も確認できる。このことから, 体積相転移温度の直前の 数 ${ }^{\circ} \mathrm{C}$ の範囲内では, 酸化状態にあるゲル微粒子は分散し, 還元状態ではゲル微粒子が凝集する振動が発現すること が予想される。この凝集塊は体積相転移温度を超えて収 縮した微粒子が立体安定力を失った事により生じたと考 えられる。ゲル微粒子を純水中に分散させ, 体積相転移 温度以上に昇温させて収縮状態にしただけではこのよう な凝集は確認されなかったため, BZ 反応を生起させる 高塩濃度下 $(>0.3 \mathrm{M})$ では粒子間の静電斥力による安 定化効果が有効に働かない事により凝集が進んだと考え

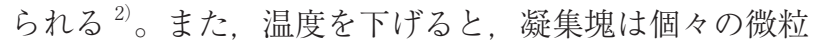
子に分散することも確認された。体積振動発現のメカニ ズムの詳細については, 以下の $3 \cdot 5$ で説明する。

\section{2 振動振幅}

$\mathrm{BZ}$ 反応は, 人間の体内で血液を循環させる役割をも つ心臓の拍動や, 生活のリズムを決める時計タンパク質 などの生命現象と似たリズムやパターンを示す。 BZ 反 応により生起されるゲル微粒子の振動波形の理解はそう いった生命現象の理解や模倣に応用できる。

実際に $\mathrm{Ru}(\mathrm{bpy})_{3}$ を固定したゲル微粒子を $\mathrm{BZ}$ 反応の 基質溶液 (マロン酸 $(\mathrm{MA})$, 臭素酸ナトリウム $\left(\mathrm{NaBrO}_{3}\right)$, 硝酸 $\left(\mathrm{HNO}_{3}\right)$ の混合溶液) に分散させ, 一定速度での 撹拌の下, 振動を生起させた。ここでは, 膨潤状態と収 縮状態において光散乱強度が異なることを利用して（膨 潤状態の方が透過率は高くなる), 透過率の時間変化か ら振動を観察した。Fig. 5 に振動挙動に対する（A）温 度および（B）微粒子濃度依存性を示す（初期基質濃度 は一定)。Fig. 5 (A) より, $28^{\circ} \mathrm{C}$ から $29^{\circ} \mathrm{C}$ に上昇すると, 振動周期が短くなり振動振幅が増加した。より高温 $\left(29.5^{\circ} \mathrm{C}\right)$ になると振動振幅の大きな減衰が観察された。一般に, $\mathrm{BZ}$ 反応の振動周期は温度上昇によって短くなる傾向を 示すため ${ }^{13)}$, 温度上昇に伴う振動周期の短縮は説明が つく。また, 温度上昇に伴う振動振幅の単調増加 $\left(28^{\circ} \mathrm{C}\right.$ $\left.\rightarrow 29^{\circ} \mathrm{C}\right)$ についても, 温度上昇に伴い一定温度下におけ る酸化／還元状態の粒子径の差が大きくなる（Fig. 4 参 照）ことにより説明がつく。29 C で確認された振幅の劇 的な増加には微粒子としての特徵, すなわちコロイド安 定性の変化が寄与していることが考えられる。一般に， コロイド安定性はイオン強度や微粒子濃度に強く依存す る。ここでは, 振動波形の劇的な変化がコロイド安定性 の変化に起因するかを確かめるために, 振動挙動に与え 


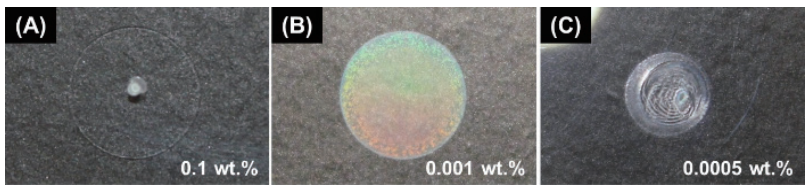

Fig. 1 （A） 0.1，（B） 0.001，（C） 0.0005 wt.\%のゲル微粒子 分散液の乾燥後の目視観察。

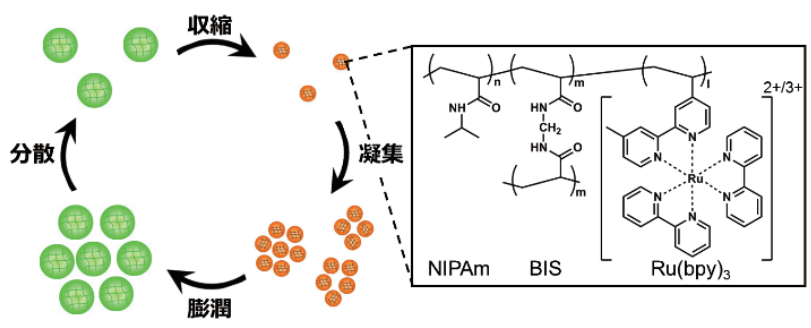

Fig. 3 自律駆動ゲル微粒子の化学構造

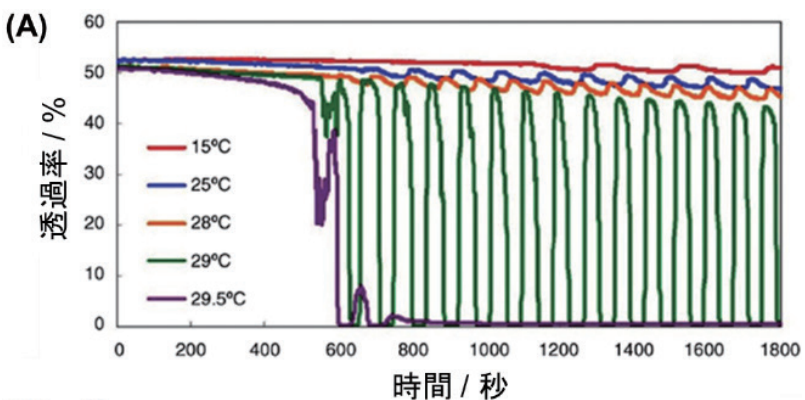

(B)

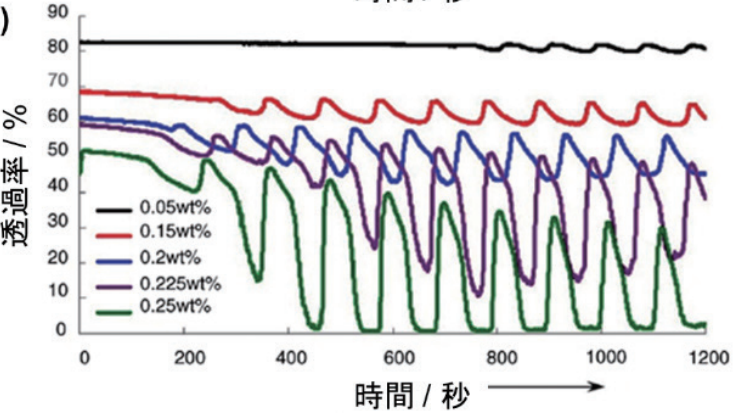

Fig. 5 自律駆動ゲル微粒子分散液の透過率振動（(A) 温度 変化，（B）ゲル微粒子濃度変化）。

る微粒子濃度の影響も調べた（Fig. 5（B））。Fig. 5（A） において劇的な振動波形変化が確認された $29^{\circ} \mathrm{C}$ (微粒 子濃度は $0.25 \mathrm{wt}$. \% ）の条件から微粒子濃度のみを減少 させたところ，BZ 反応に見られる一般的な振動波形に 戻った。このことから，コロイド安定性の周期的な変化 が生じている可能性が高まった。

\section{$3 \cdot 3$ 振動周期}

生命現象には, 心臓の拍動は約 1 秒, 時計タンパク質 の分子機構は約 24 時間など様々な周期が存在する。生 命現象の理解のためには周期の制御は重要となる。ここ では，自律駆動ゲル微粒子の振動周期の反応基質濃度依 存性について述べる。

$\mathrm{BZ}$ 反応の振動周期 $\left(P_{\mathrm{osc}}\right)$ は温度の他に反応基質濃度

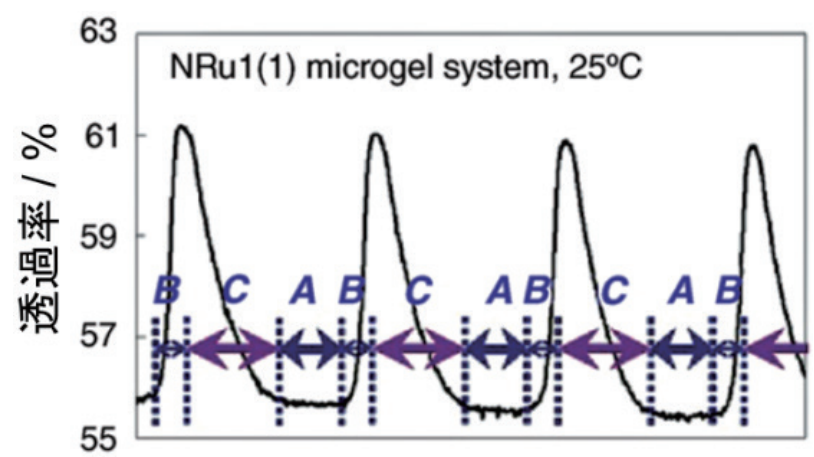

時間 / 秒

Fig. 7 典型的な振動波形

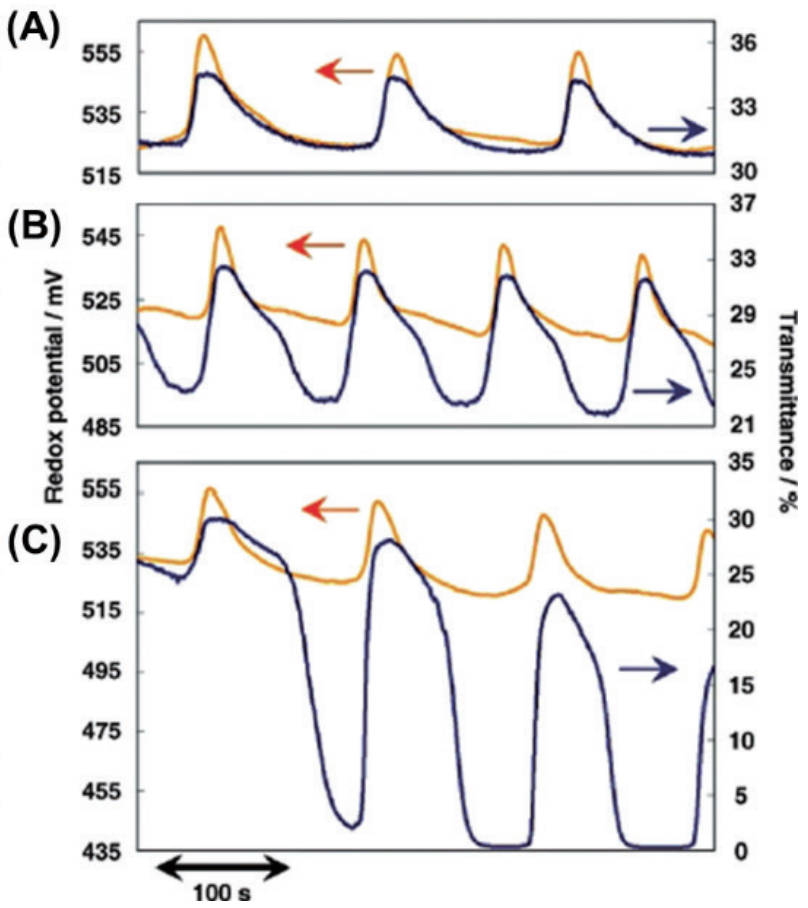

Fig. 8 自律駆動ゲル微粒子分散液の酸化還元電位測定 (橙), 透過率測定（青)，（(A) $25{ }^{\circ} \mathrm{C}$ ，（B） $27{ }^{\circ} \mathrm{C} ，(\mathrm{C})$ $\left.27.5^{\circ} \mathrm{C}\right)$ 。

に依存する。金属触媒 $\left(\mathrm{Ru}(\mathrm{bpy})_{3}\right)$ がゲル微粒子に固定 されることの振動周期への影響をみるため, $\mathrm{Ru}(\mathrm{bpy})_{3}$ 水溶液の振動周期と比較する。Fig. 6 に, 温度 $25^{\circ} \mathrm{C}$ 一定下で, 反応基質の濃度 $\left([\mathrm{MA}]_{0},\left[\mathrm{NaBrO}_{3}\right]_{0}\right.$, $\left.\left[\mathrm{HNO}_{3}\right]_{0}\right)$ に対する $P_{\mathrm{osc}}$ の変化を示した。 $P_{\mathrm{osc}}$ は $2 つ$ 目 から 6 つ目までの振動の周期を平均したものである。溶 液と微粒子分散液の間には違いが生じている。全ての場 合において, 反応基質の濃度が増加するに比例して $P_{\mathrm{osc}}$ は短くなる。溶液と比較して, 微粒子分散液の濃度依存 性は MA の場合は変化が大きいが, $\mathrm{NaBrO}_{3}$ と $\mathrm{HNO}_{3}$ の 場合は小さい。また，溶液と微粒子分散液の間には, $\mathrm{MA}$ 濃度が高く, $\mathrm{NaBrO}_{3}$ と $\mathrm{HNO}_{3}$ 濃度が低いときに大 きな差があるが, $\mathrm{MA}$ 濃度が低く, $\mathrm{NaBrO}_{3}$ と $\mathrm{HNO}_{3}$ 濃 

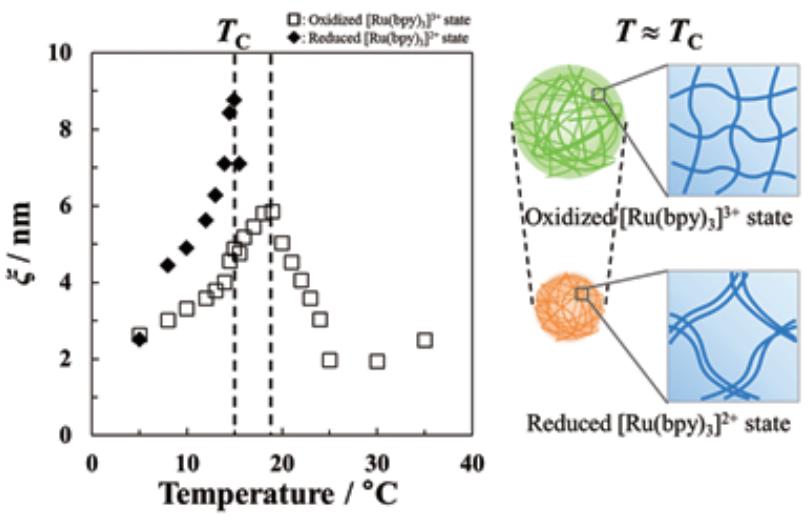

Fig. 9 自律駆動ゲル微粒子の相関長 $\xi$ の温度依存性

(A)

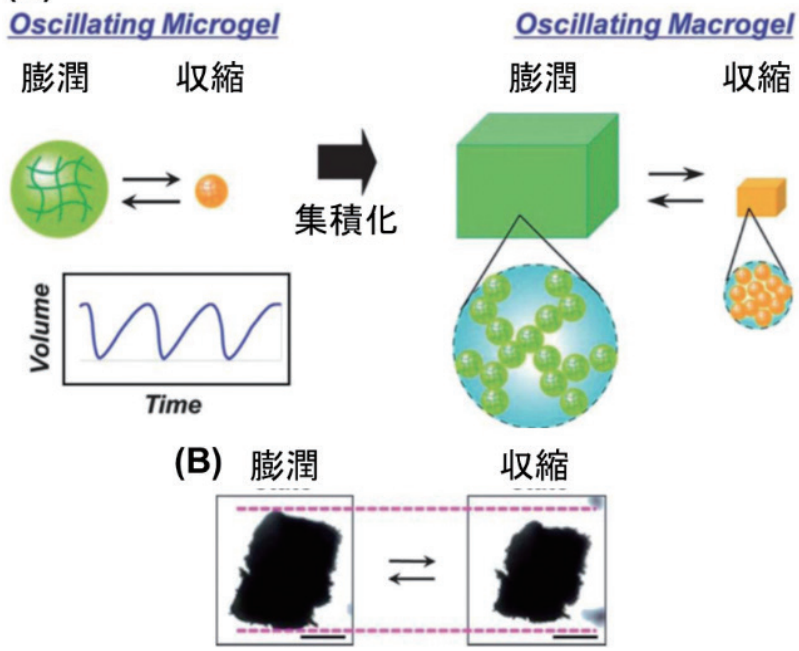

Fig. 10 自律駆動ゲル微粒子の集積化によるソフトアクチュ エーター

度が高いときには差はない。BZ 反応には 80 以上の主要 な反応が含まれているため，この結果は反応における全 ての現象を説明はできないが, 定性的に $P_{\mathrm{osc}}$ をコントロー ルするための指標になる。この他にも，ゲル微粒子内部 の架橋密度と振動周期についての関係も明らかにしてい $3^{14)}$ 。

\section{$3 \cdot 4$ 分散 $/$ 凝集振動の発現}

振動波形を考察することで, より詳細な情報を得るこ とができる。ここで生じていると考えられる「分散/凝 集振動」を振動波形と照らし合わせながら説明する。 Field-Körös-Noyes（FKN）メカニズムによると，BZ 反 応は 3 つの主要なプロセス（プロセス $\mathrm{A}$ は臭化物イオ ンの消費, プロセス $\mathrm{B}$ は $\mathrm{HBrO}_{2}$ の自触媒反応, プロセ ス C は臭化物イオンの生成）から説明される ${ }^{15)}$ 。

Field-Koros-Noyes (FKN) mechanism
$\mathrm{A}: \mathrm{BrO}_{3}^{-}+2 \mathrm{Br}^{-}+3 \mathrm{H}^{+} \rightarrow 3 \mathrm{HOBr}$
$\mathrm{B}: \mathrm{BrO}_{3}{ }^{-}+\mathrm{HBrO}_{2}+2 \mathrm{M}_{\mathrm{red}}+3 \mathrm{H}^{+} \rightarrow 2 \mathrm{HBrO}_{2}+2 \mathrm{M}_{\mathrm{ox}}+\mathrm{H}_{2} \mathrm{O}$
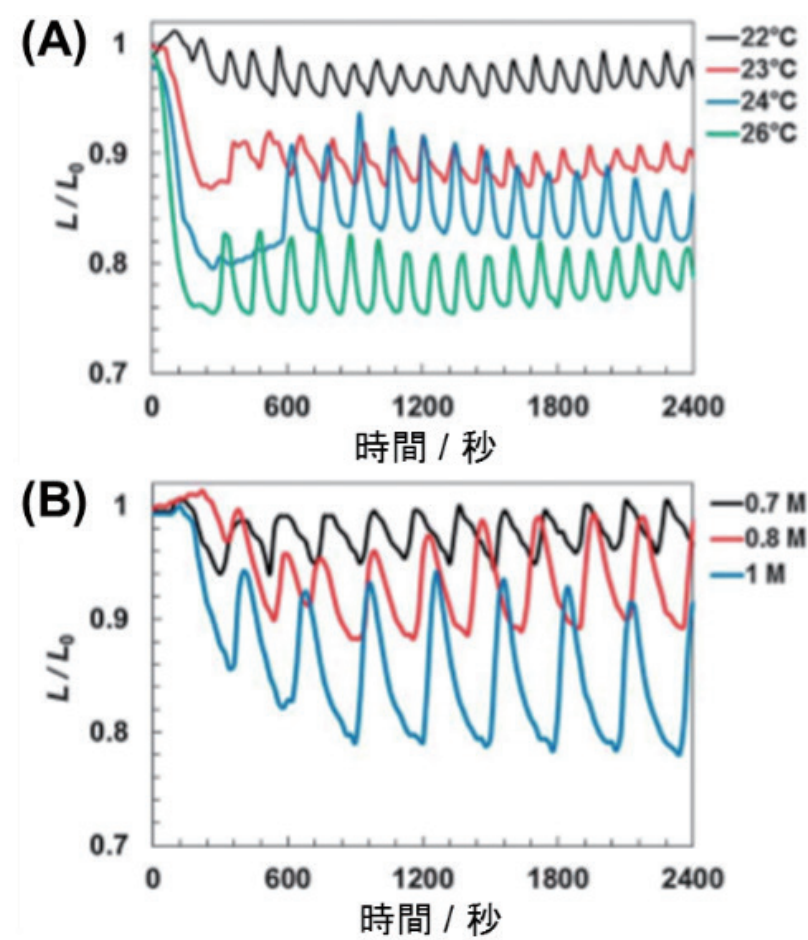

(C)

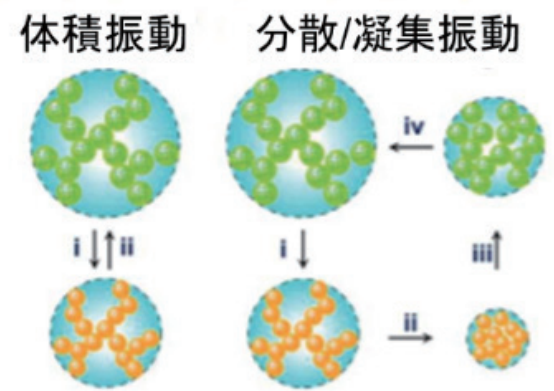

Fig. 11 自律駆動ゲル微粒子集積体の体積振動（（A）温度 依存性，（B） $20^{\circ} \mathrm{C}$ における硝酸濃度依存性，（C) 体積振動時におけるゲル微粒子集積体内部のイメー ジ図)。

$\mathrm{C}: 2 \mathrm{M}_{\mathrm{ox}}+\mathrm{MA}+\mathrm{BrMA} \rightarrow f \mathrm{Br}^{-}+2 \mathrm{M}_{\mathrm{red}}+$ other products

$\mathrm{Ru}(\mathrm{bpy})_{3}$ の酸化／還元状態の観点から述べると，プ ロセス Bにおいて酸化状態へ, プロセス Cで還元状態へ, そしてプロセス A では還元状態で一定となる。そのた め, BZ 反応の酸化還元振動と同期し, 膨潤収縮変化を 示すゲル微粒子分散液は Fig. 7 のような透過率の振動波 形を示す。ここでは, プロセス Cにおいて透過率が劇 的に減少し（ $61 \% \rightarrow 56 \%)$ ，プロセス B が始まると同 時に透過率が上昇していることがわかった（56\% ～ $61 \%) 。 フ ゚ ロ セ ス \mathrm{C} て ゙ は \mathrm{Ru}(\mathrm{bpy})_{3}$ が還元状態となりゲ ル微粒子が収縮する。透過率が劇的に減少したことは, 微粒子が凝集し可視光をより散乱することによると考え られる。凝集した原因としては，還元状態の $\mathrm{Ru}(\mathrm{bpy})_{3}$ を有する微粒子が体積相転移温度を超えたことにより立 


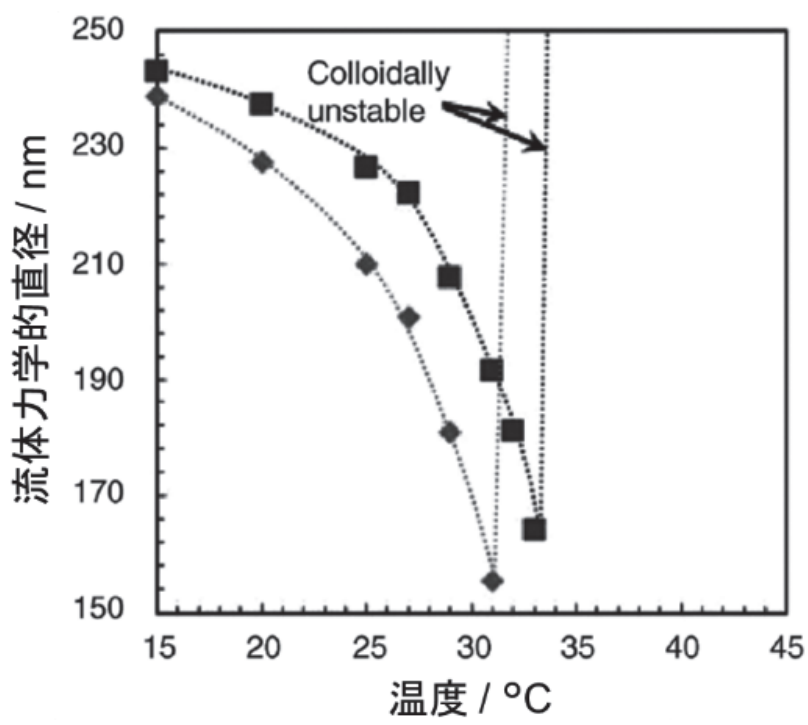

Fig. 4 温度に対する流体力学的直径の変化 : 酸化状態 $\left(\mathrm{Ru}(\mathrm{bpy})_{3}{ }^{3+}\right), \diamond$ : 還元状態 $\left(\mathrm{Ru}(\mathrm{bpy})_{3}{ }^{2+}\right)$

体安定力が消失し，コロイド安定性を保つ斥力が極端に 弱まったことによると考えられる。また，この微粒子凝 集塊は温度を下げ膨潤させると，再び個々の微粒子に分 散したことから，プロセスBにおける透過率の劇的な 上昇は，凝集塊が解れ，個々の微粒子に分散したことを 示していると考えられる。

分散/凝集振動の波形は他の方法からも観察され, そ の一つに酸化還元電位測定がある ${ }^{14)} 。$ Fig. 8 は, 透過率 変化と酸化還元電位の波形である。酸化還元電位の増加 は酸化状態 $\left(\mathrm{Ru}(\mathrm{bpy})_{3}{ }^{3+}\right)$ の濃度の増加を意味する。 低温（(A) $25^{\circ} \mathrm{C}$ ) では，透過率変化と酸化還元電位の 波形は良く一致している。これはゲル微粒子の膨潤／収 縮の体積振動が周期的な化学反応と同期している事を示 す。対して, より高い温度 ((B) $27^{\circ} \mathrm{C}$, (C) $\left.27.5^{\circ} \mathrm{C}\right)$ で は，一致しておらず，ゲル微粒子が分散／凝集振動して いる事を示す。還元状態 $\left(\mathrm{Ru}(\mathrm{bpy})_{3}{ }^{2+}\right)$ の割合が高く なるとき，ゲル微粒子の凝集により，透過率が大きく減 少している。凝集から再分散することは，ゲル微粒子間 の対ポテンシャルエネルギーが最小にないためであり， 弱く, 可逆性の凝集であることを結果づける ${ }^{16)}$ 。また, 分散/凝集振動と体積振動は粘度变化からも説明されて いる ${ }^{3,17)}$ 。

\section{$3 \cdot 5$ 自律駆動ゲル微粒子のナノ構造変化と機能の相 関の解明へ}

上述したように，自律駆動ゲル微粒子の体積振動や分 散／凝集振動は，微粒子分散液の透過率及び粘度の時間 変化により確認できるが，分子論的なゲル微粒子の構造 変化の理解は進んでおらず, 振動挙動の詳細なメカニズ ムは不明確であった。そこで筆者らは, 高分子などソフ
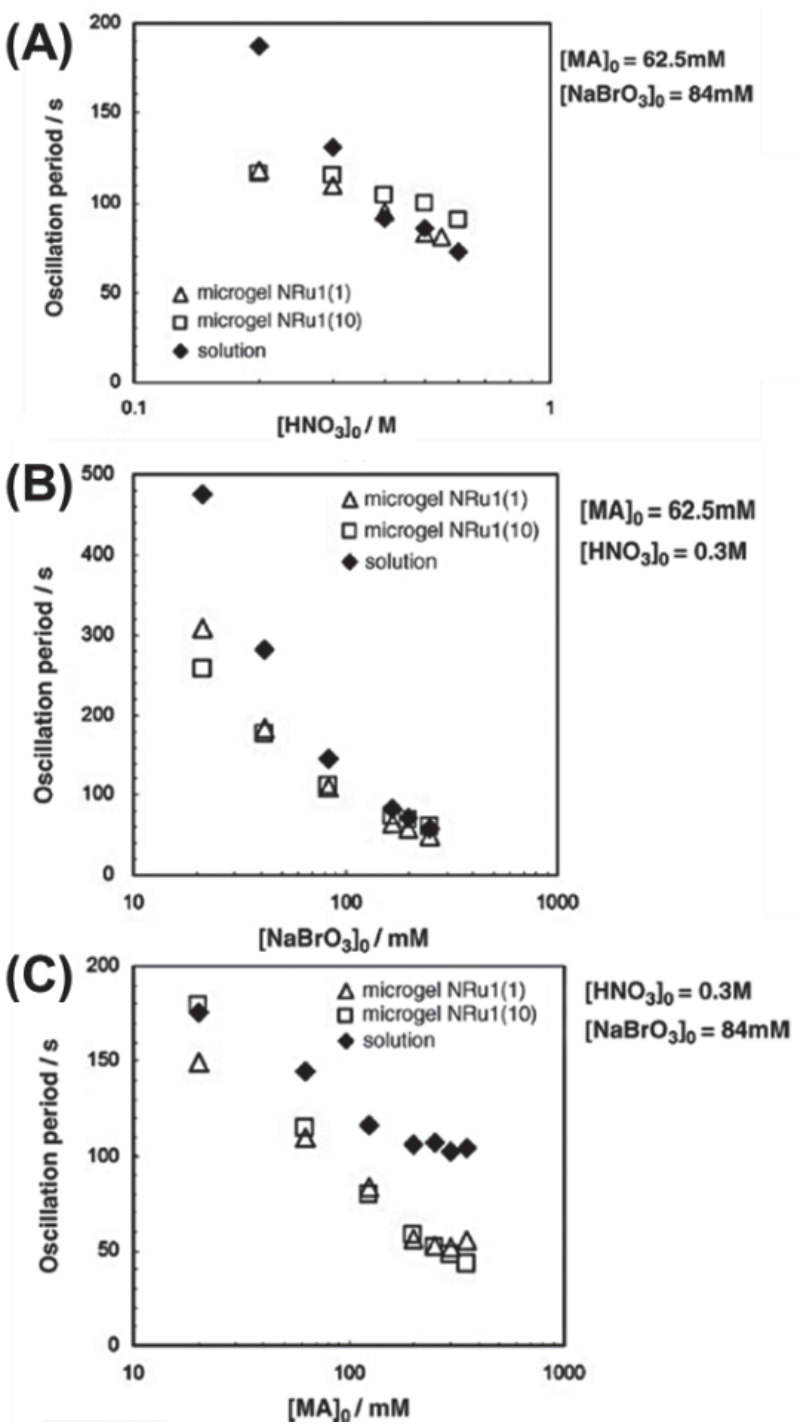

Fig. 6 振動周期の反応基質濃度依存性 ( (A) $\mathrm{HNO}_{3}$ 濃度変化, (B) $\mathrm{NaBrO}_{3}$ 濃度変化, (C) $\mathrm{MA}$ 濃度変化, $\triangle$ : ゲ ル微粒子 (BIS $1 \mathrm{~mol} \%$ \%), $\square$ : ゲル微粒子 (BIS $10 \mathrm{~mol} \%$ \%), Ru(bpy) ${ }_{3}$ 水溶液)。

トマテリアルの微細構造評価の手法として有効な小角 $\mathrm{X}$ 線散乱法 $(\mathrm{SAXS})$ に注目した。特に, 広大な空間 $(0.07$ $\left.\mathrm{nm}^{-1}<q<20 \mathrm{~nm}^{-1}\right)$ を網羅する小角・広角 $\mathrm{X}$ 線散乱法 (SWAXS) に着目した ${ }^{18)}$ 。この手法は分子レベルの構 造解析が可能であり, 自律駆動ゲル微粒子の振動挙動に おける微細構造変化を調査し, 挙動の解明に繋がる知見 を得ることを目的とした。

SWAXS 法により得られた散乱曲線に対し，ゲルネッ トワークの電子密度摇らぎを記述する Ornstein-Zernike 式を含む 5 つの式により精度よく解析でき，ゲルの摇ら ぎの相関長（）（又は, メッシュサイズ）を定量的に得 ることに成功した。そして, 自律駆動ゲル微粒子の臨界 凝集温度において, 相関長は pNIPAm ゲル微粒子と同 様に発散様挙動を示す事がわかった。更に，体積振動が 
発現する一定温度下では，膨潤状態より収縮状態の方が 相関長は大きくなる事を見出した ${ }^{19)}$ 。従って, 自律駆 動ゲル微粒子は, 臨界凝集温度において, 柔らかさなど の物理的性質が膨潤／収縮状態で, 直観とは逆の方向に 変化していると考えられる。即ち, Fig. 9 に示す体積の 大きな時よりも, 収縮時の方が, ゲル網目構造が潰され やすくなっているのである。また, 自律駆動ゲル微粒子 の散乱曲線から，高分子主鎖間の干渉性散乱の寄与がブ ロードであるため，ゲル微粒子内部に疎水的なポリマー リッチドメインが殆ど形成されていない事が判明し，自 律駆動ゲル微粒子が収縮状態においても振動挙動が継続 する理由が明らかになった。

\section{$3 \cdot 6$ ゲル微粒子集積化自律駆動ソフトアクチュエー ター}

これまで紹介してきた自律駆動ゲル微粒子は，単一の 成分として機能を発揮するに留まらず，集団として振る 舞うことで, その高次構造固有の機能を発揮する事もで きる。特に生命現象に目を向けると，例えば，心臓は， 心筋細胞の高次集積体として捉えることができ，個々の 心筋細胞中のアクチンとミオシンのミクロな運動によ り，周期的な拍動が生起する。そこで，個々の自律駆動 ゲル微粒子を心筋細胞と見立て, それらを集積化させて バルク体とする事で, あたかも心臓の拍動のような, 大 きな体積振動振幅を生起する自律駆動ソフトアクチュ エーターの開発を試みた $(\text { Fig. 10 })^{20)}$ 。

個々の自律駆動ゲル微粒子を化学結合させるために, $N$-(3-aminopropyl) methacrylamide hydrochloride （APMA）を導入し，ゲル微粒子中のアミノ基間を glutaric dialdehyde により架橋する事で，ゲル微粒子集積 体（マクロゲル）を得た。得られた集積体の体積振動挙 動を観察し, マクロゲルの長さの経時変化を計測した (Fig. 11)。まず，マクロゲルの体積振動の温度依存性を 観察した $\left([\mathrm{MA}]=100 \mathrm{mM},\left[\mathrm{NaBrO}_{3}\right]=150 \mathrm{mM},\left[\mathrm{HNO}_{3}\right]\right.$ $=500 \mathrm{mM})$ (Fig. $11(\mathrm{~A}))$ 。低温 $\left(22^{\circ} \mathrm{C}\right)$ では, 体積振 動振幅は小さくなった $(\sim 0.03)$ 。昇温につれて, $23^{\circ} \mathrm{C}$ 以上では初期状態におけるマクロゲルのサイズが小さく なり, 元のサイズに戻らなかった。これは, マクロゲル 中のゲル微粒子同士が凝集していると考えられ，更に高

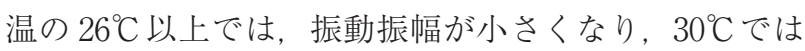
体積振動挙動が見られなかった。次に, 体積振動挙動の 硝酸濃度依存性を観察した所, 体積振動振幅の増加が見 られた（Fig. 11（B））。これは, 硝酸濃度を増加させると， ゲル微粒子の体積相転移温度が減少するため, $\mathrm{Ru}(\mathrm{bpy})_{3}$ の酸化還元状態における粒子径差が大きくなり, 体積振 動振幅が増加したものと考えられる。更に, 従来の塊状 重合で作製した自律駆動マクロゲルと比較すると，体積
振動振幅が大きくなるという結果も得られている。Fig. 11 (A), （B）で示した体積振動時における振幅の大小 を模式的に表す（Fig.11（C））。低温時, または低硝酸 濃度下では，マクロゲルを構成する個々のゲル微粒子の 単純な膨潤／収縮（体積）振動が生起するため, マクロ ゲルのサイズは初期状態まで戻ったと考えられる。一方, 高温時，または高硝酸濃度下では，マクロゲルを構成す るゲル微粒子の分散/凝集振動の生起により, 体積振動 振幅が増大したと考えられる。このように，ゲル微粒子 により高次構造体を構築することで, 従来のゲルでは成 し得ない新機能の発現に成功した。

\section{4 おわりに}

もちろん, 似たような化学振動反応はいくつかあるの だが，扱いやすさはBZ 反応に勝るものはいまだ見当た るものはない。はじめに, 「BZ 反応にばかり頼っては だめだ」といったありがたい批評があるといったが，や はりそれでも BZ 反応を活かした材料システムはすごい と感じる。ただ振動させればよいのではなく，私たち生 命体の周りには多くの周期が存在していることを考える と, それらの普遍性や制御メカニズムをより一層理解す る事は, 長期的な意味での医療や新産業に役立つものと 思われる。実際に, 新学術領域『生命分子システムにお ける動的秩序形成と高次機能発現』では, 生体分子の離 合集散を追うだけでは理解が難しく，著者らが取り組む 超分子系を用いたシステムを統合して解決するプロジェ クトを展開している。いわば, このゲル微粒子を生命分 子のモデルとして見立てているわけである。こうした「ユ ニーク」なゲル微粒子の基礎研究が, 生命現象の理解の 一助になることを大いに期待している。

\section{謝 辞}

自律駆動ゲル微粒子研究のきっかけを与えて頂きまし た吉田亮教授 (東京大学) に, この場を借りて深く御礼 を申し上げます。

\section{文 献}

1) A. N. Zaikin, A. M. Zhabotinsky, Nature, 225, 535 (1970).

2) D. Suzuki, T. Sakai, R. Yoshida, Angew. Chem. Int. Ed., 47, 917 (2008).

3) D. Suzuki, H. Taniguchi, R. Yoshida, J. Am. Chem. Soc., 131, 12058 (2009).

4) R. D. Deegan, O. Bakajin, T. F. Dupont, G. Huber, S. R. Nagel, T. A. Witten, Nature, 389, 827 (1997).

5) R. H. Pelton, P. Chibante, Colloids Surf., 20, 247 (1986).

6) S. Tsuji, H. Kawaguchi, Langmuir, 21, 8439 (2005).

7) K. Horigome, D. Suzuki, Langmuir, 28, 12962 (2012). 
8) D. Suzuki, K. Horigome, Langmuir, 27, 12368 (2011).

9) D. Suzuki, K. Horigome, J. Phys. Chem. B, 117, 9073 (2013).

10) T. Ishiwatari, M. Kawagishi, M. Mitsuishi, J. Polym. Sci. Polym. Chem. Ed., 22, 2699 (1984).

11) T. Yamaguchi, L. Kuhnert, Z. Nagy-Ungvarai, S. C. Mueller, B. Hess, J. Phys. Chem., 95, 5831 (1991).

12) R. Yoshida, T. Takahashi, T. Yamaguchi, H. Ichijo J. Am. Chem. Soc., 118, 5134 (1996).

13) P. Ruoff, Physica D, 84, 204 (1995).

14) D. Suzuki, R. Yoshida, Macromolecules, 41, 5830 (2008).

15) R. J. Field, E. Körös, R. M. Noyes, J. Am. Chem. Soc.,
94, 8649 (1972)

16) M. Rasmusson, A. Routh, B. Vincent, Langmuir, 20, 3536 (2004).

17) H. Taniguchi, D. Suzuki, R. Yoshida, J. Phys. Chem. B, 114, 2405 (2010).

18) T. Kureha, T. Sato, D. Suzuki, Langmuir, 30, 8717 (2014).

19) S. Matsui, T. Kureha, Y. Nagase, K. Okeyoshi, R. Yoshida, T. Sato, D. Suzuki, Langmuir, 31, 7228 (2015).

20) D. Suzuki, T. Kobayashi, R. Yoshida, T. Hirai, Soft Matter, 8, 11447 (2012). 